\title{
Could the Effect of Order-Disorder in Garnet be Important for Upper Mantle Petrology?
}

\author{
Geiger, C.A.
}

Mineralogisch-Petrographisches Institut der Universität Kiel, Olshausenstr. 40, 24098 Kiel, Germany

Many phase equilibrium experiments in the CMAS system have been made to understand the thermodynamic relations of model peridotitic compositions. The garnets in this system can be described and their thermodynamic properties modeled by the grossular-pyrope $\left(\mathrm{Ca}_{3} \mathrm{Al}_{2} \mathrm{Si}_{3} \mathrm{O}_{12}-\right.$ $\mathrm{Mg}_{3} \mathrm{Al}_{2} \mathrm{Si}_{3} \mathrm{O}_{12}$ ) join. A thermodynamic description of this solid solution is also important in formulating garnet activity models used in various geothermobarometers applicable to mantle xenoliths, because of the large nonidealities associated with it. A good model for this join would be especially useful, for example, in describing the P-T conditions of grospydite xenoliths.

We have shown recently (Bosenick et al., 1995; Bosenick et al., submitted) that synthetic pyropegrossular garnets synthesized between 1000 and $1400^{\circ} \mathrm{C}$ are not completely disordered, but show some degree of short-range order of the $\mathrm{Mg}$ and $\mathrm{Ca}$ cations. This effects their $\mathrm{S}^{\text {conf }}$, which enters into, for example, the P-T position of the spinel to garnet peridotite transition as governed by the Clausius-Clapeyron equation :

$$
\frac{\mathrm{dP}}{\mathrm{dT}}=\frac{\Delta \mathrm{S}}{\Delta \mathrm{V}}
$$

The curvature of this transition is dependent, among other factors, on the entropy of garnet (Wood and Holloway, 1984) and, hence, the degree of order-disorder. Moreover, it appears that the volumes of garnet solid solutions depend slightly upon their structural state.

The volume of mixing of pyrope-grossular garnets has been determined a number of times over the past forty years. However, until recently no good consensus could be reached as to their behavior (for a review see Bosenick and Geiger, 1997). Therefore, all the previous volume data from the PyGr binary were reanalyzed in order investigate potential differences in the volume of mixing behavior between the different studies. Volume data from six investigations were taken, where pyrope-grossular garnets were synthesized over a range of temperature from 980 to $1400{ }^{\circ} \mathrm{C}$ with different experimental set-ups. The data were arbitrarily separated into two groups, those synthesized above and below 1100 o C. This temperature was chosen, because it represents approximately the $\mathrm{T}$ below which $\mathrm{Mg}$-Ca order can be quenched in from high-pressure experiments (Bosenick et al., submitted).

The data appear to show the following (Figure 1): In pyrope-rich compositions those garnets synthesized below $1100{ }^{\circ} \mathrm{C}$ tend to have relatively smaller molar volumes compared to those synthesized at higher temperatures, while the reverse is true for grossular-rich compositions. The lower temperature data set can be described by ideal mixing behavior $\left(\Delta \mathrm{V}^{\mathrm{ex}}=0\right)$, while the higher temperature data can be represented by a regular mixing model $\left(\mathrm{WV}^{\mathrm{V}}=1.2 \pm 0.4 \mathrm{~cm} 3 / \mathrm{mole}\right)$. Both models should be considered estimates, because of the lack of volume data over certain compositions. In addition, differences in experimental conditions and, more importantly, the structural state of garnet in the various studies can not be evaluated. 
These results demonstrate the necessity of undertaken crystal chemical investigations of garnet before extracting thermodynamic properties. In addition, the structural state of natural garnets in peridotites and eclogites needs to be investigated.

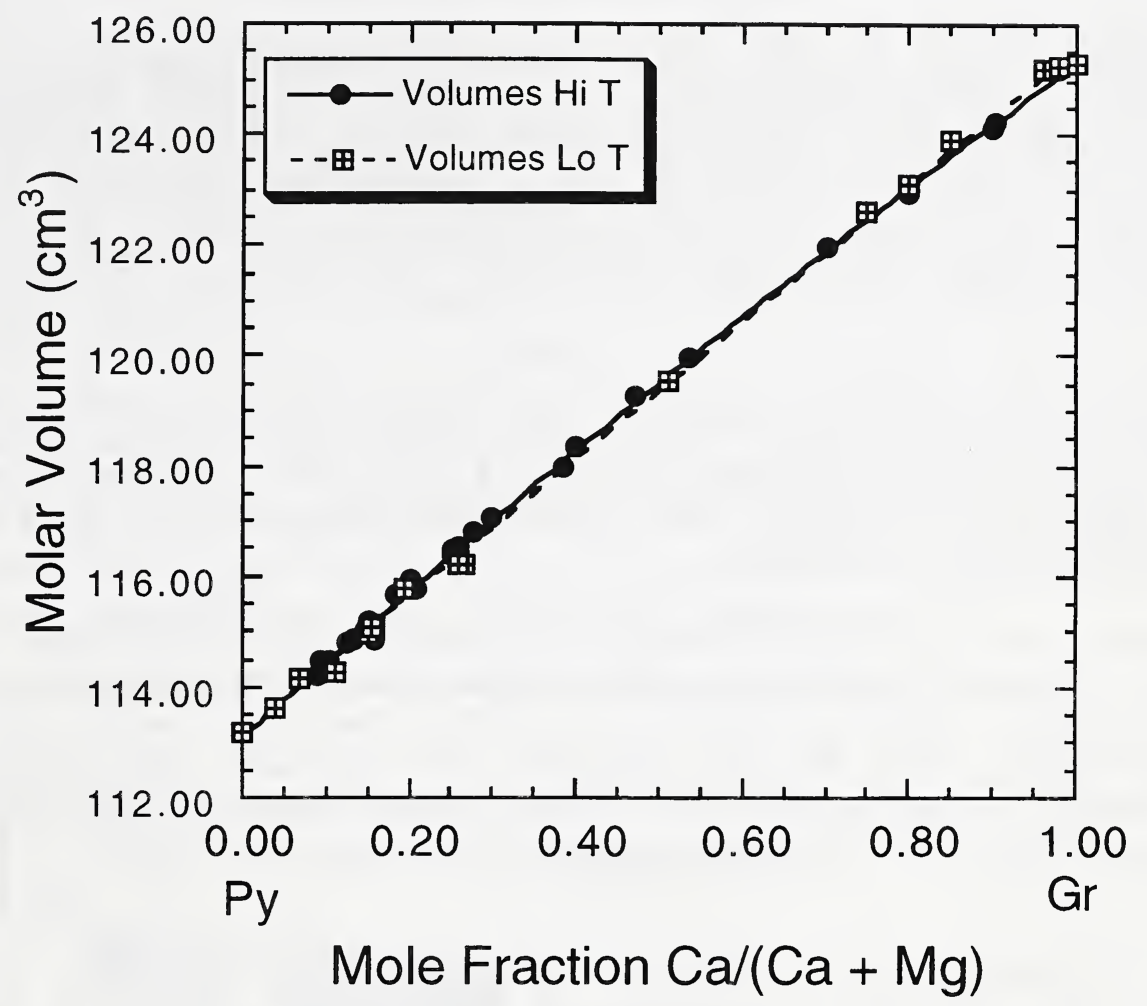

\section{References}

Bosenick, A., and Geiger, C.A., 1997, Powder diffraction study of synthetic pyrope-grossular garnets between 20 and 295 K: Journal of Geophysical Research, Solid Earth, 102, B10, p. 2264922657.

Bosenick, A., Geiger, C.A., Schaller, T., and Sebald, A., 1995, A ${ }^{29}$ Si MAS NMR and IR spectroscopic investigation of synthetic pyrope-grossular garnet solid solutions: Am. Min., 80, p. 691-704.

Bosenick, A., Geiger, C.A., and Phillips, B.L., submitted, Temperature dependent Mg-Ca ordering in synthetic pyrope-grossular garnets: Am. Min.

Wood, B.J., and Holloway, J.R., 1984, A thermodynamic model for subsolidus equilibria in the system $\mathrm{CaO}-\mathrm{MgO}-\mathrm{Al}_{2} \mathrm{O}_{3}-\mathrm{SiO}_{2}$ : Geochim. Cosmochim. Acta, 48, p. 159-176. 